\title{
Erratum to: 'Multimodal perioperative care plus immunonutrition versus traditional care in total hip arthroplasty: a randomized pilot study'
}

Miguel Aprelino Alito ${ }^{1}$ and José Eduardo de Aguilar-Nascimento $2,3,4^{*}$

Unfortunately, the original version of this article [1] contained an error. There is an error in Fig. 2 of this article. It has been labelled incorrectly and the groups were inverted. The correct figure with correct labels has been included here.

\footnotetext{
Author details

${ }^{1}$ Brazilian Society of Orthopedics and Traumatology, Cuiabá, MT, Brazil. ${ }^{2}$ Federal University of Mato Grosso, Cuiabá, Brazil. ${ }^{3}$ UNIVAG, Varzea Geande, Brazil. ${ }^{4}$ Rodovia Helder Candia, Cond. Country casa 15, Cuiabá 78048-150,
} Brazil.

Received: 9 May 2016 Accepted: 9 May 2016

Published online: 18 May 2016

\section{References}

1. Alito MA, de Aguilar-Nascimento JE. Multimodal perioperative care plus immunonutrition versus traditional care in total hip arthroplasty: a randomized pilot study. Nutr J. 2016;15:34.

* Correspondence: aguilar@terra.com.br

${ }^{2}$ Federal University of Mato Grosso, Cuiabá, Brazil

${ }^{3}$ UNIVAG, Varzea Geande, Brazil

Submit your next manuscript to BioMed Central and we will help you at every step:

- We accept pre-submission inquiries

- Our selector tool helps you to find the most relevant journal

- We provide round the clock customer support

- Convenient online submission

- Thorough peer review

- Inclusion in PubMed and all major indexing services

- Maximum visibility for your research

Submit your manuscript at

www.biomedcentral.com/submit 


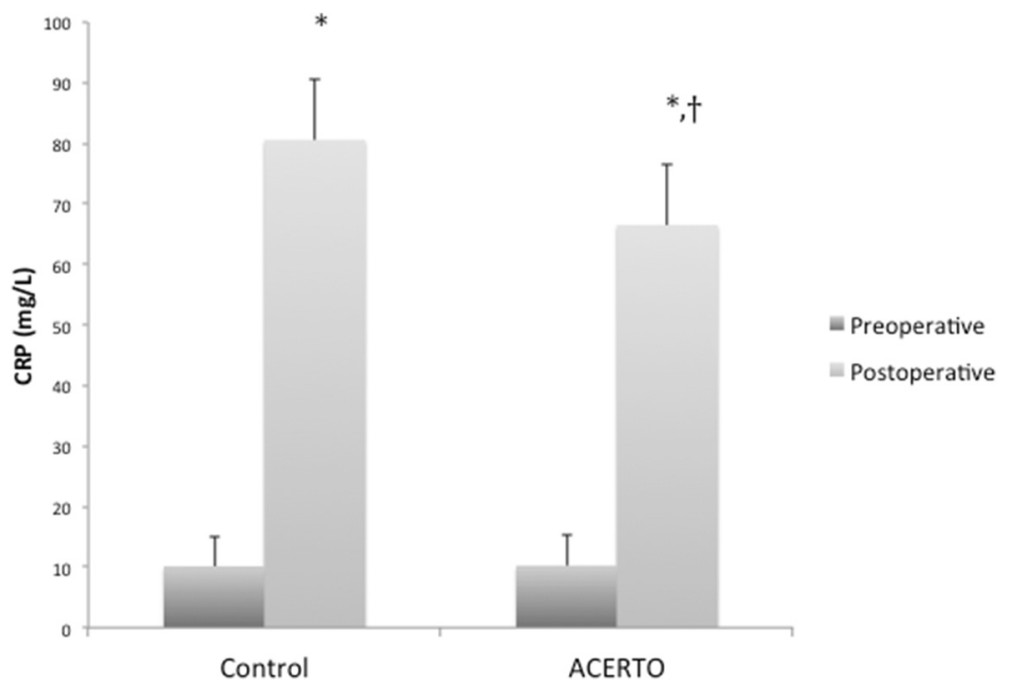

Fig. 2 Pre- and postoperative values of C-reactive protein (CRP) in the two groups. ${ }^{*} P<0.05$ versus preoperative. ${ }^{\dagger} P<0.05$ versus Control group 